Methods of Analysis by the U.S. Geological Survey Organic Geochemistry Research Group-Determination of Dissolved Isoxaflutole and Its Sequential Degradation Products, Diketonitrile and Benzoic Acid, in Water Using Solid-Phase Extraction and Liquid Chromatography/ Tandem Mass Spectrometry

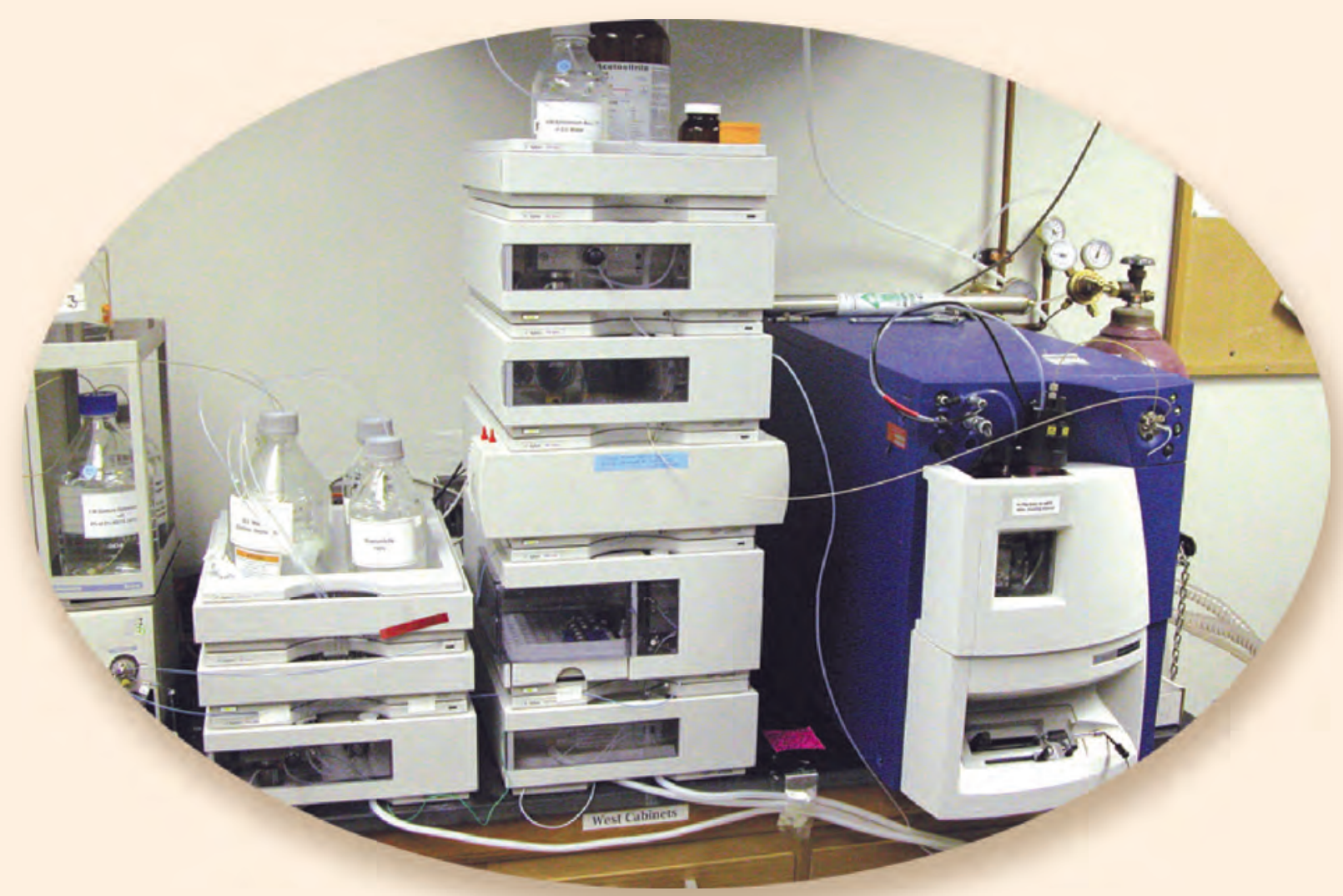

Techniques and Methods 5-A9 



\section{Methods of Analysis by the U.S. Geological Survey Organic Geochemistry Research Group-Determination of Dissolved Isoxaflutole and Its Sequential Degradation Products, Diketonitrile and Benzoic Acid, in Water Using Solid-Phase Extraction and Liquid Chromatography/Tandem Mass Spectrometry}

By Michael T. Meyer, Edward A. Lee, and Elisabeth A. Scribner

Techniques and Methods 5-A9 


\section{U.S. Department of the Interior DIRK KEMPTHORNE, Secretary}

\section{U.S. Geological Survey \\ Mark D. Myers, Director}

\section{U.S. Geological Survey, Reston, Virginia: 2007}

For product and ordering information:

World Wide Web: http://www.usgs.gov/pubprod

Telephone: 1-888-ASK-USGS

For more information on the USGS — the Federal source for science about the Earth, its natural and living resources, natural hazards, and the environment:

World Wide Web: http://www.usgs.gov

Telephone: 1-888-ASK-USGS

Any use of trade, product, or firm names is for descriptive purposes only and does not imply endorsement by the U.S. Government.

Although this report is in the public domain, permission must be secured from the individual copyright owners to reproduce any copyrighted materials contained within this report.

Suggested citation:

Meyer, M.T., Lee, E.A., and Scribner, E.A., 2007, Methods of analysis by the U.S. Geological Survey Organic Geochemistry Research Group - determination of dissolved isoxaflutole and its sequential degradation products, diketonitrile and benzoic acid, in water using solid-phase extraction and liquid chromatography/tandem mass spectrometry: U.S. Geological Survey Techniques and Methods, book 5, chap. A9, 13 p.

Cover: Photograph showing liquid chromatograph/mass spectrometer used in analysis of isoxaflutole and its sequential degradation products, diketonitrile and benzoic acid. 


\section{Contents}

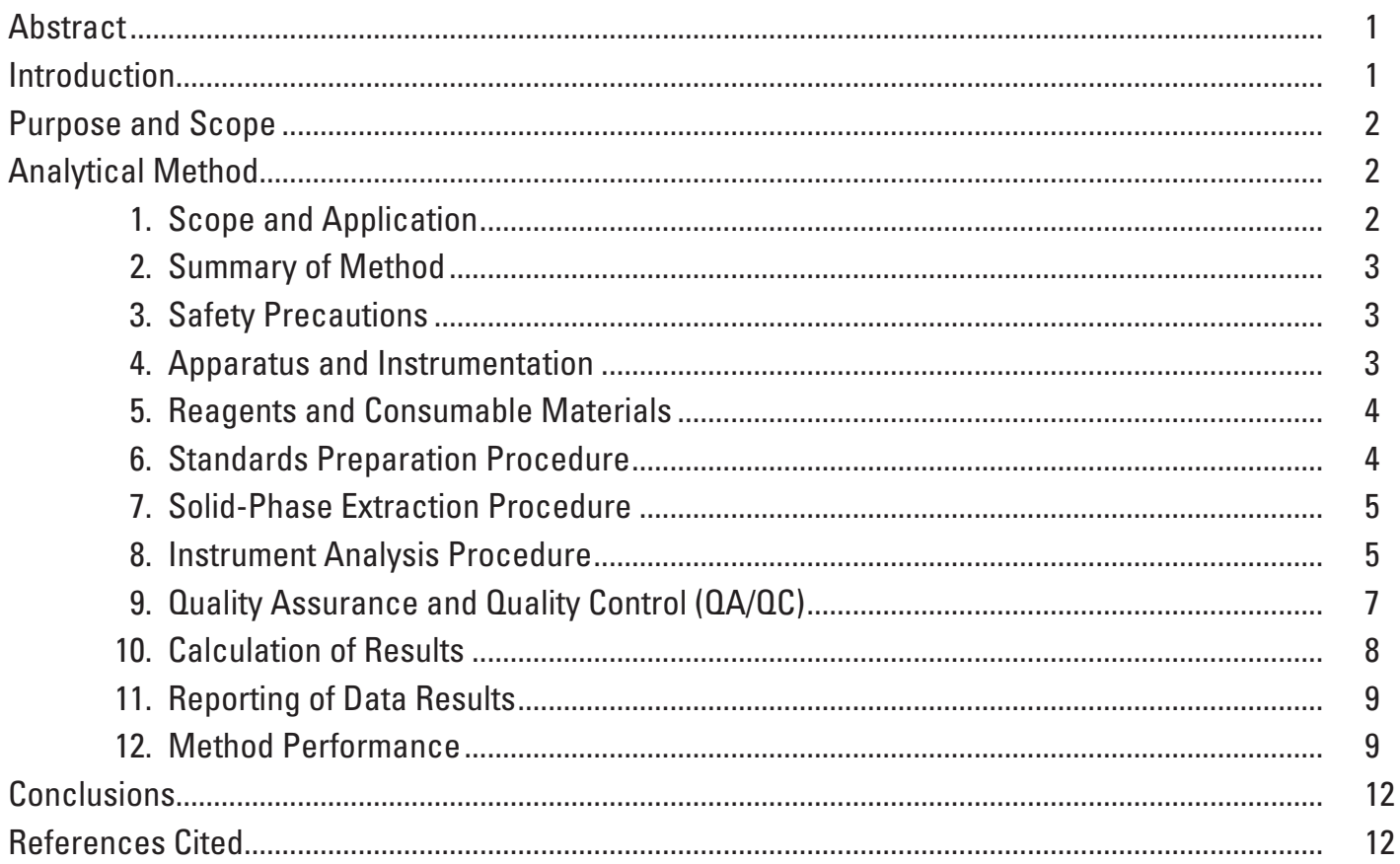

\section{Figure}

1. Diagram showing chemical structures of isoxaflutole and its sequential degradation products, diketonitrile and benzoic acid analogue.

\section{Tables}

1. U.S. Geological Survey method number, method code, parameter code, Organic Geochemistry Research Laboratory code, and molecular weight for isoxaflutole and its sequential degradation products, diketonitrile and benzoic acid analogue.....

2. Liquid chromatography/tandem mass spectrometry analytical sequence for use in determining isoxaflutole and its sequential degradation products, diketonitrile and benzoic acid, in water.

3. Retention times and multiple-reaction monitoring molecular (precursor)-ion and product-ion transitions for isoxaflutole, and its two sequential degradation products, and the internal and surrogate standards.

4. Summary of mean solid-phase extraction recovery and relative standard deviation percentages in buffered reagent water for isoxaflutole, diketonitrile, benzoic acid, and the surrogate standard

5. Summary of mean concentrations, standard deviations, and mean normalized percentage of theoretical spiked concentrations and relative percentage standard deviations for isoxaflutole, diketonitrile, benzoic acid, and the surrogate standard in four water matrices. 
6. Combined mean concentrations, standard deviations, and combined mean normalized percentage of theoretical spiked concentrations and relative percentage standard deviations for isoxaflutole, diketonitrile, benzoic acid, and the surrogate standard in four water matrices.

\section{Conversion Factors, Abbreviated Water-Quality Units, and Other Abbreviations}

\begin{tabular}{lcl}
\hline \multicolumn{1}{c}{ Multiply } & \multicolumn{1}{c}{ By } & \multicolumn{1}{c}{ To obtain } \\
\hline acre & 4,047 & square meter $\left(\mathrm{m}^{2}\right)$ \\
kilopascal $(\mathrm{kPa})$ & 0.1450 & pound-force per square inch $\left({\left.\mathrm{lb} / \mathrm{in}^{2}\right)}^{2}\right.$ \\
liter $(\mathrm{L})$ & 0.2642 & gallon $(\mathrm{gal})$ \\
microliter $(\mu \mathrm{L})$ & $2.642 \times 10^{-7}$ & gallon $(\mathrm{gal})$ \\
micrometer $(\mu \mathrm{m})$ & $3.937 \times 10^{-5}$ & inch (in.) \\
millimeter $(\mathrm{mm})$ & 0.03937 & inch (in.) \\
nanogram $(\mathrm{nm})$ & $3.527 \times 10^{-11}$ & ounce $(\mathrm{oz})$ \\
ounce, fluid $(\mathrm{oz})$ & 0.02957 & liter $(\mathrm{L})$ \\
gram $(\mathrm{g})$ & 0.002204 & pound $(\mathrm{lb})$ \\
\hline
\end{tabular}

Temperature can be converted to degrees Celsius $\left({ }^{\circ} \mathrm{C}\right)$ or degrees Fahrenheit $\left({ }^{\circ} \mathrm{F}\right)$ by the equations:

$$
\begin{aligned}
& { }^{\circ} \mathrm{C}=5 / 9\left({ }^{\circ} \mathrm{F}-32\right) \\
& { }^{\circ} \mathrm{F}=9 / 5\left({ }^{\circ} \mathrm{C}\right)+32 .
\end{aligned}
$$

\section{Abbreviated Water-Quality Units}

$\operatorname{gram}(\mathrm{g})$

liter per hour (L/hr)

microgram per liter $(\mu \mathrm{g} / \mathrm{L})$

microgram per milliliter $(\mu \mathrm{g} / \mathrm{mL})$

microliter per minute $(\mu \mathrm{L} / \mathrm{min})$

milligram (mg)

milligram per milliliter $(\mathrm{mg} / \mathrm{mL})$

milliliter (mL)

milliliter per minute $(\mathrm{mL} / \mathrm{min})$

nanogram per microliter $(\mathrm{ng} / \mu \mathrm{L})$ 


\section{Other Abbreviations or Acronyms Used in This Report}

$\pm$

$\mathrm{ACN}$

ACS

BA

c-18

CAS

$\mathrm{cc}$

$\mathrm{CCV}$

$\mathrm{COB}$

$\mathrm{DF}$

DKN

ESI

HLB

HPLC

ISTD

$\mathrm{kPa}$

LC/MS/MS

LD

MDL

MRL

MRM

$\mathrm{m} / \mathrm{z}$

$\mathrm{M}-\mathrm{H}$

OGRL

QA

QC

$\mathrm{r}^{2}$

$\mathrm{RF}$

$\mathrm{RRT}_{c}$

RT

SD

SPE

USEPA

USGS

$\mathrm{v} / \mathrm{v}$

$\mathrm{V}$

WP plus or minus

acetonitrile

American Chemical Society

benzoic acid

carbon-18

Chemical Abstracts Service

cubic centimeter

continuous calibration verification

carryover blank

dilution factor

diketonitrile

electrospray ionization

hydrophilic-liophilic balance

high-performance liquid chromatography

internal standard

kilopascal

liquid chromatography/tandem mass spectrometry

laboratory duplicate

method detection limit

method reporting level

multiple-reaction monitoring

mass-to-charge ratio

molecular-hydrogen

Organic Geochemistry Research Laboratory

quality assurance

quality control

correlation coefficient

radio frequency

relative retention time

expected retention time

standard deviation

solid-phase extraction

U.S. Environmental Protection Agency

U.S. Geological Survey

volume-to-volume

voltage

water pollution 


\title{
Methods of Analysis by the U.S. Geological Survey Organic Geochemistry Research Group-Determination of Dissolved Isoxaflutole and Its Sequential Degradation Products, Diketonitrile and Benzoic Acid, in Water Using Solid-Phase Extraction and Liquid Chromatography/ Tandem Mass Spectrometry
}

\author{
By Michael T. Meyer, Edward A. Lee, and Elisabeth A. Scribner
}

\section{Abstract}

An analytical method for the determination of isoxaflutole and its sequential degradation products, diketonitrile and a benzoic acid analogue, in filtered water with varying matrices was developed by the U.S. Geological Survey Organic Geochemistry Research Group in Lawrence, Kansas. Four different water-sample matrices fortified at 0.02 and $0.10 \mu \mathrm{g} / \mathrm{L}$ (micrograms per liter) are extracted by vacuum manifold solid-phase extraction and analyzed by liquid chromatography/tandem mass spectrometry using electrospray ionization in negative-ion mode with multiple-reaction monitoring (MRM). Analytical conditions for mass spectrometry detection are optimized, and quantitation is carried out using the following MRM molecular-hydrogen (precursor) ion and product (p) ion transition pairs: 357.9 (precursor), $78.9(\mathrm{p})$, and 277.6 (p) for isoxaflutole and diketonitrile, and 267.0 (precursor), 159.0 (p), and 223.1 (p) for benzoic acid. 2,4-dichlorophenoxyacetic acid- $\mathrm{d}_{3}$ is used as the internal standard, and alachlor ethanesulfonic acid- $\mathrm{d}_{5}$ is used as the surrogate standard.

Compound detection limits and reporting levels are calculated using U.S. Environmental Protection Agency procedures. The mean solid-phase extraction recovery values ranged from 104 to 108 percent with relative standard deviation percentages ranging from 4.0 to 10.6 percent. The combined mean percentage concentration normalized to the theoretical spiked concentration of four water matrices analyzed eight times at 0.02 and $0.10 \mu \mathrm{g} / \mathrm{L}$ (seven times for the reagent-water matrix at $0.02 \mu \mathrm{g} / \mathrm{L}$ ) ranged from approximately 75 to 101 percent with relative standard deviation percentages ranging from approximately 3 to 26 percent for isoxaflutole, diketonitrile, and benzoic acid. The method detection limit (MDL) for isoxaflutole and diketonitrile is $0.003 \mu \mathrm{g} / \mathrm{L}$ and $0.004 \mu \mathrm{g} / \mathrm{L}$ for benzoic acid. Method reporting levels (MRLs) are $0.011,0.010$, and $0.012 \mu \mathrm{g} / \mathrm{L}$ for isoxaflutole, diketonitrile, and benzoic acid, respectively. On the basis of the calculated MRLs and MDLs and evaluation of the signal-to-noise ratios for each compound, the MRLs and MDLs are set at 0.010 and $0.003 \mu \mathrm{g} / \mathrm{L}$, respectively, for all three compounds.

\section{Introduction}

Isoxaflutole, a member of the benzoyl isoxazole family, is a low-application-rate preemergence herbicide for control of annual broadleaf weeds and some grasses in field corn and sugar cane (Pallet and others, 2001). Isoxaflutole, also known by its trade name Balance, degrades sequentially through hydrolysis to the biologically active diketonitrile (DKN) degradation product through the opening of the isoxazole ring which then degrades to a benzoic acid analogue (BA; Viviani and others, 1998) that is biologically inactive. Diketonitrile also is more water soluble than isoxaflutole, and therefore, its transport to surface or ground water is a concern (Lin and others, 2002).

For example, isoxaflutole is applied in Iowa at a rate that is 8 percent of the rate of atrazine application and 4 percent of the rate of metolachlor application and is only applied to 24 percent of the number of acres to which atrazine is applied (U.S. Department of Agriculture, 2004). Thus, the frequent detection of the sequential herbicidally active degradation product of isoxaflutole, DKN, and BA was unexpected during a 2004 study to document the occurrence of these compounds and to compare their occurrence with that of more commonly measured herbicides such as atrazine and metolachlor (Scribner and others, 2006). Analytical results of 75 water samples collected in 2004 showed that isoxaflutole was detected in four of the samples collected during the post-planting (May-June) period. Diketonitrile was detected in 53 water samples, and 
benzoic acid was detected in 41 water samples collected from all three sampling periods. Metolachlor was the most frequently detected acetamide parent (59 of 60 samples) during all three sampling periods, and atrazine was the most detected triazine parent compound with 65 detections of 69 samples during all three sampling periods.

\section{Purpose and Scope}

The purpose of this report is to describe a new analytical method. The method described in this report was developed by the U.S. Geological Survey (USGS) Organic Geochemistry Research Laboratory (OGRL), Lawrence, Kansas, to analyze dissolved isoxaflutole [5-cyclopropyl-4-(2-methylsulfonyl4-(trifluoromethylbenzoyl) isoxazole] and its sequential degradation products (fig. 1), diketonitrile [1-(2-methylsulfonyl-4-trifluoromethylphenyl)-2-cyano-3-cyclopropyl propan1,3-dione], and benzoic acid analogue [2-methylsulfonyl4-(trifluoromethyl) benzoic acid], by solid-phase extraction (SPE) and liquid chromatography/tandem mass spectrometry (LC/MS/MS) using electrospray ionization in negative-ion mode. This report also provides method detection and reporting limits, mean extraction recoveries, and relative standard deviations and mean concentration of two spiked levels in four water matrices.

The method of analysis described in this report is assigned a USGS method number O-2140-07, USGS method code LCM47, and OGRL code LCIX. These unique codes represent the automated method of analysis as it is described in the report and can be used to identify the method. This method will contribute to an improved understanding of the occurrence, persistence, and transport of isoxaflutole and its degradation products in the environment.

\section{Analytical Method}

Organic Compounds and Parameter Codes: Isoxaflutole and its sequential degradation products, diketonitrile and benzoic acid, in filtered water using solid-phase extraction and liquid chromatography/mass spectrometry/mass spectrometry, USGS method number O-2140-07, USGS method code LCM47, and OGRL code LCIX.

\section{Scope and Application}

This method is suitable for the determination of low-level concentrations (in micrograms per liter) of isoxaflutole and its two sequential degradation products, DKN and BA, in water samples (table 1). Because suspended particulate matter is removed from the samples by filtration, the method is suitable only for filtered-phase compounds. The calibration range for the method is equivalent to concentrations from 0.005 to $0.200 \mu \mathrm{g} / \mathrm{L}$.

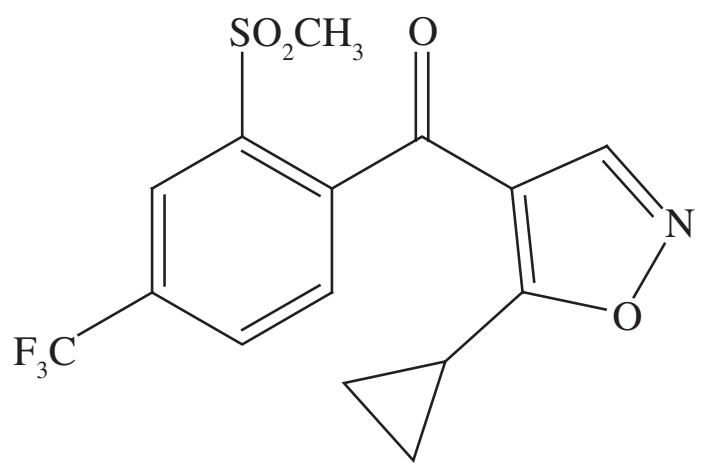

Isoxaflutole [5-cyclopropyl-4-(2-methylsulfonyl-4(trifluoromethylbenzoyl) isoxazole]

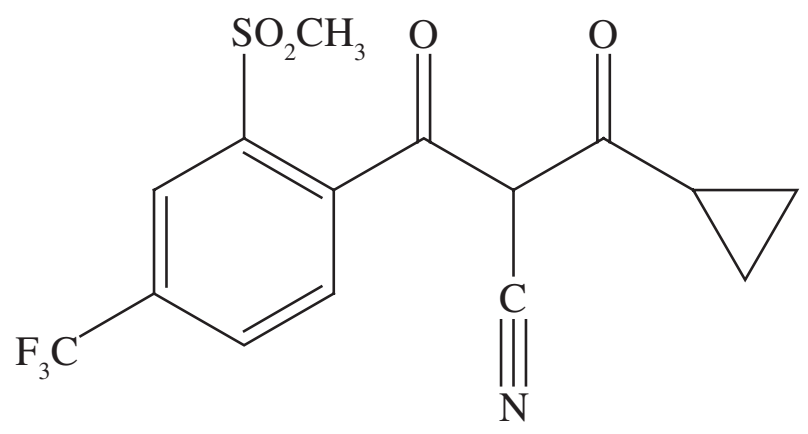

Diketonitrile of isoxaflutole [1-(2-methylsulfonyl-4trifluoromethylphenyl)-2-cyano-3-cyclopropyl propan-1, 3-dione]

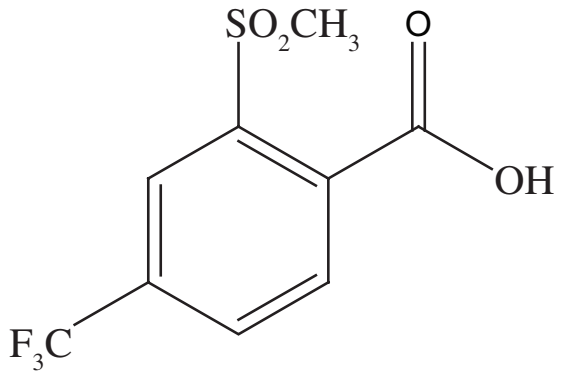

Benzoic acid analogue [2-methylsulfonyl-4(trifluoromethyl) benzoic acid]

Figure 1. Chemical structures of isoxaflutole and its sequential degradation products, diketonitrile and benzoic acid analogue. 
Table 1. U. S. Geological Survey method number, method code, parameter code, Organic Geochemistry Research Laboratory code, and molecular weight for isoxaflutole and its sequential degradation products, diketonitrile and benzoic acid analogue.

[--, not applicable; USGS, U.S. Geological Survey; OGRL, Organic Geochemistry Research Laboratory]

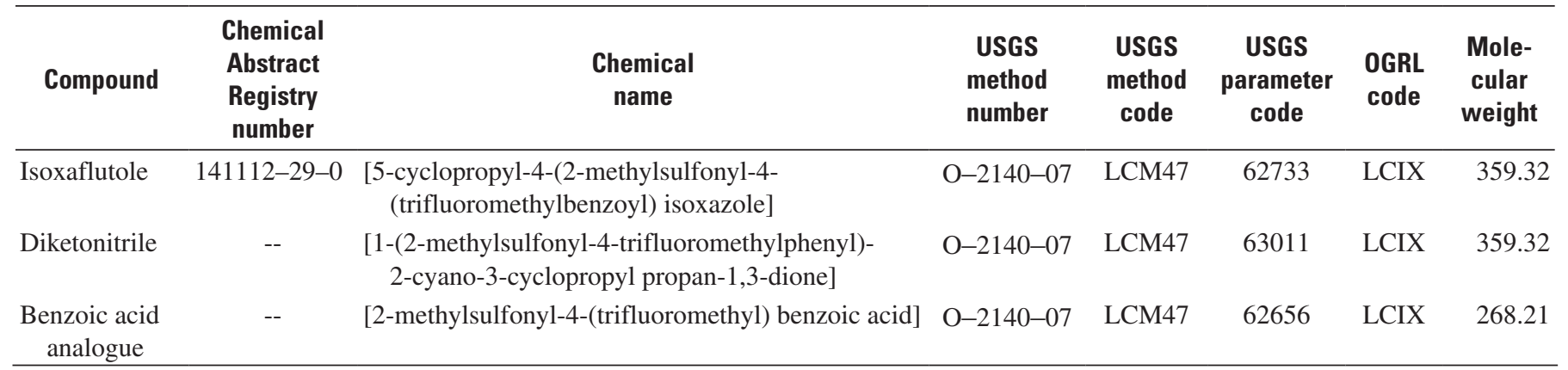

\section{Summary of Method}

Water samples are collected in the field by using the methods outlined in either Shelton (1994), Wilde and others (1998), or Webb and others (1999). Samples are then chilled immediately and shipped to the OGRL and refrigerated at approximately $4{ }^{\circ} \mathrm{C}$ until analysis.

In the laboratory, filtered water samples spiked with surrogate standards are passed through an Oasis hydrophilicliophilic balanced (HLB) cartridge (Waters Corporation, Milford, Massachusetts). The adsorbed compounds are eluted from the cartridge with 50:50 methanol and acetonitrile and spiked with an internal standard. The sample eluate is evaporated further under nitrogen.

The sample components are separated, identified, and quantified by injecting an aliquot of the concentrated sample extract into a LC/MS/MS with electrospray ionization (ESI) in negative-ion mode using multiple-reaction monitoring (MRM). Compounds separated on the LC are identified by comparing the retention times of the mass spectral signals against the retention times of standards analyzed under the same conditions used for the samples. Compounds are identified further by measuring pre-optimized MRM molecular (precursor) ion and product ion transitions. The concentration of each identified compound is calculated by determining the ratio of the MS area response produced by the quantitation daughter ion to the MS area response produced by the quantitation daughter ion of the internal standard.

\section{Safety Precautions}

The following safety precautions are followed:

3.1 All steps involving organic solvents and strong acids are performed under a well-vented fume hood.

3.2 Appropriate personal protective equipment is used during the handling of reagents and chemicals.

3.3 The electrospray waste exhaust and the vacuum pump exhaust are vented through a laboratory hood system.
3.4 Precautions are taken when handling columns or working with the spray chamber of the MS as temperatures are in excess of $300{ }^{\circ} \mathrm{C}$. These areas are allowed to cool before touching them.

\section{Apparatus and Instrumentation}

The following apparatus and instrumentation are used:

4.1 Analytical balance - capable of accurately weighing $0.050 \mathrm{~g}+0.0001 \mathrm{~g}$.

4.2 Autopipettes - 10 - to 10,000- $\mu \mathrm{L}$, variable-volume autopipettes with disposable plastic tips (Rainin, Woburn, Massachusetts).

\subsection{Mechanical vortex mixer.}

4.4 Test tube rack-40 holders for 10-mL conical bottom centrifuge tubes.

4.5 Vacuum manifold for SPE.

4.6 Cartridges-Oasis hydrophilic-liophilic balanced, $6 \mathrm{cc}$, 500-mg, extraction cartridges (Waters Corporation, Milford, Massachusetts).

4.7 Automated solvent evaporator-Heat bath temperature maintained at $45^{\circ} \mathrm{C}$ and the nitrogen gas pressure at $103 \mathrm{kPa}$ (Turbovap LV, Zymark, Inc., Hopkinton, Massachusetts).

4.8 Analytical column-Keystone Scientific 250- x 4.6-mm Betasil C-18 column with 5- $\mu \mathrm{m}$ packing (Bellefonte, Pennsylvania).

4.9 HPLC/MS benchtop system-Agilent (Wilmington, Delaware) model 1100 HPLC with autoinjector and MS detector and Waters (Milford, Massachusetts) Quattro Micro API triple-stage quadrupole mass spectrometer system using ESI mode. 
4.10 HPLC system - computer with Agilent chemstation software.

4.11 Mass spectrometer system software-MassLynx software (Waters Corporation, Milford, Massachusetts) is used to operate the MS and acquire and store data. QuanLynx software (Waters Corporation, Milford, Massachusetts) is used for quantitation of compounds for the MS.

\section{Reagents and Consumable Materials}

The following reagents and consumable materials are used:

5.1 Analytical standards-solutions of isoxaflutole, diketonitrile, and benzoic acid (U.S. Environmental Protection Agency, Fort Meade, Maryland), the surrogate, and the internal standard (ISTD), and calibration curve.

5.2 Internal standard solution-The ISTD, 2,4-dichlorophenoxyacetic acid- $\mathrm{d}_{3}$, is purchased from Cambridge Isotope Laboratory, Andover, Massachusetts.

5.3 Surrogate standard solution-The surrogate, alachlor ethanesulfonic acid (ESA)- $\mathrm{d}_{5}$, is provided by Monsanto (St. Louis, Missouri).

5.4 Reagent water-generated by purification of tapwater through activated charcoal filter and deionization with a high-purity, mixed-bed resin, followed by another activated charcoal filtration, and finally distillation in an autostill (Barnstead, Dubuque, Iowa).

5.5 Formic acid - chemical reagent, American Chemical Society (ACS) grade.

5.6 Glacial acetic acid - chemical reagent, ACS grade.

5.7 Humic acid—chemical reagent.

5.8 Water pollution (WP) minerals $A$ and $B$

\subsection{Solvents-}

5.9.1 Acetonitrile, ACS and HPLC grade.

5.9.2 Methanol, ACS and HPLC grade.

5.10 Sample bottles-baked 4-oz amber glass bottles (Boston round) withTeflon-lined lids (VWR, West Chester, Pennsylvania).

5.11 Disposable plastic test tubes-(Fisher Scientific, Pittsburg, Pennsylvania).

5.12 Sample filters - nominal 0.7- $\mu$ m glass-fiber filters (Gilson, Middleton, Wisconsin).

5.13 Plastic rack-40 holes for tubes.
5.14 SPE cartridges-Oasis HLB extraction, Prospekt (10-mm x 2-mm) cartridges (Waters, Milford, Massachusetts).

5.15 Gas for mass spectrometer-nitrogen; argon.

\section{Standards Preparation Procedure}

6.1 Primary standard solutions-Individual stock solutions (corrected for purity) of $1.0 \mathrm{mg} / \mathrm{mL}$ for isoxaflutole and its sequential degradation products, DKN and BA, are prepared by accurately weighing, to the nearest $0.0001 \mathrm{~g}$, $50 \mathrm{mg}$ of the pure material into a $50-\mathrm{mL}$ volumetric flask with acetonitrile (ACN). The solutions are stored at $-10^{\circ} \mathrm{C}$.

6.2 Intermediate composite standard-30 mL of intermediate standard mix containing $12.3 \mathrm{ng} / \mu \mathrm{L}$ of isoxaflutole, DKN, and BA are prepared by diluting individual $1-\mathrm{mg} / \mathrm{mL}$ stock solutions into acetonitrile.

6.3 Working standard mix-Using volumetric procedures, a $5-\mathrm{mL}, 0.123-\mathrm{ng} / \mu \mathrm{L}$ working standard mix is prepared from the intermediate standard mix by diluting it 1:100 into $90 / 10$ percent formic acid (1.1 percent, aqueous)/acetonitrile solution and then stored at $-10{ }^{\circ} \mathrm{C}$. The working standard mix is prepared frequently.

6.4 Internal standard solution-The ISTD, 2,4-dichlorophenoxyacetic acid- $\mathrm{d}_{3}$, is prepared, using volumetric procedures, at a concentration of $0.615 \mathrm{ng} / \mu \mathrm{L}$ in methanol from a $1-\mathrm{mg} / \mathrm{mL}$ stock solution.

6.5 Surrogate standard solution-The surrogate standard, alachlor ESA- $\mathrm{d}_{5}$, is prepared, using volumetric procedures, at a concentration of $0.615 \mathrm{ng} / \mu \mathrm{L}$ in methanol from a $1-\mathrm{mg} / \mathrm{mL}$ stock solution.

6.6 Preparation of reagent-water samples-Reagent-water blank and spike samples, including the calibration samples of $0.005,0.010,0.050,0.100$, and $0.200 \mu \mathrm{g} / \mathrm{L}$, are prepared for extraction in 4-oz baked, amber glass bottles, by adding $75 \mathrm{~mL}$ of reagent water, $0.5 \mathrm{~mL}$ of $1-\mathrm{mg} / \mathrm{mL}$ aqueous humic acid solution (Sigma Aldrich, Allentown, Pennsylvania), and $0.25 \mathrm{~mL}$ of water pollution (WP) minerals A and B (Ultra Scientific, North Kingstown, Rhode Island). Spiked reagent-water (CCV, continuous calibration verification) and matrix-spiked samples are all spiked at $0.10 \mu \mathrm{g} / \mathrm{L}$. The appropriate amount of working standard mix then is added to each reagent-water spike, and deionized water is added to bring the final volume of the calibration solutions to $123 \mathrm{~mL}$.

6.7 Preparation of environmental samples - The filtered environmental samples are stored in 4-oz baked, amber glass bottles. If a sample bottle contained less than 123 $\mathrm{mL}$, reagent water is added to bring the volume of the 
sample to $123 \mathrm{~mL}$. The volume added is recorded, and the dilution factor is calculated. Samples selected for matrix spikes are prepared at concentrations of $0.10 \mu \mathrm{g} / \mathrm{L}$ by adding $100 \mu \mathrm{L}$ of the working standard mix.

6.8 Adding solutions-All laboratory and environmental samples are prepared by adding $100 \mu \mathrm{L}$ of $0.615-\mathrm{ng} / \mu \mathrm{L}$ surrogate and $100 \mu \mathrm{L}$ of glacial acetic acid to all samples to help stabilize the isoxaflutole. The bottles then are capped and mixed well.

\section{Solid-Phase Extraction Procedure}

The SPE procedure requires a 40-position plastic testtube rack, a 12- or 24-position vacuum manifold, 10- or 15-mL glass conical bottom test tubes, Oasis HLB SPE cartridges $(6 \mathrm{~mL}, 500 \mathrm{mg})$, and a nitrogen evaporation apparatus with a hot-water bath. SPE preparation steps include the following:

7.1 Sample preparation-A full extraction set consists of 60 environmental samples plus four laboratory duplicates, four environmental matrix spikes, two reagent-water (CCV) spikes, five reagent-water carryover blanks, and five reagent-water calibration standard samples (table 2).

7.2 Cartridge preparation - The appropriately labeled SPE cartridges are placed on a vacuum manifold and rinsed with $5 \mathrm{~mL}$ of 50:50 methanol and acetonitrile followed by $5 \mathrm{~mL}$ of reagent water.

7.3 Loading sample to cartridges-SPE cartridge adapters are connected with tubing to the top of each SPE cartridge, and the end of the tubing placed into the sample bottles. Vacuum is applied, and the manifold adjusted to load sample onto cartridge in 15 to 20 minutes.

7.4 Rinsing cartridges-Cartridges are rinsed by adding 3 $\mathrm{mL}$ of 1-percent formic acid (aqueous) under vacuum for 1 minute.

7.5 Eluting compounds from the cartridge-Appropriately labeled 10-mL glass, conical bottomed tubes are placed in the vacuum manifold test-tube rack, making certain that the vacuum manifold valve stems are inside or directly above each test tube. Four milliliters (4 mL) of 50:50 methanol/acetonitrile are added to each cartridge. A small amount of vacuum is applied to begin flow through the cartridge, and then the vacuum is turned off. After the solvent mixture drips through the cartridge, another $4 \mathrm{~mL}$ of 50:50 methanol/acetonitrile is passed through each cartridge. The test tubes are removed from the vacuum manifold. The second set of labeled test tubes are placed into the vacuum manifold rack. The SPE cartridges are eluted with two more 4-mL aliquots of 50:50 methanol and acetonitrile. The test tubes are removed from the vacuum manifold.

7.6 Spiking of internal standard-Add $100 \mu \mathrm{L}$ of $0.615-\mathrm{ng} / \mu \mathrm{L}$ ISTD solution to the first set of test tubes and gently vortex.

7.7 Evaporation-All samples in test tubes are placed in preheated $45^{\circ} \mathrm{C}$ Turbovap and the lid closed. Nitrogen gas flow is turned on slowly to $15 \mathrm{lb} / \mathrm{in}^{2}$, and the sample eluates are evaporated. After all sample eluates have evaporated to $4 \mathrm{~mL}$ or less, the sample eluate from the second set of test tubes is combined with the sample eluates in the first set of test tubes. If volume is reduced to $1 \mathrm{~mL}$ or less in a test tube from the second set, $1 \mathrm{~mL}$ of 50:50 methanol/acetonitrile is added to the test tube and gently vortexed before adding it to the appropriate test tube from the first set. Sample eluates are reduced to a final volume of $200 \mu \mathrm{L}$.

7.8 Transfer to vials_-Sample eluates then are transferred to 11-mm, plastic autosampler vials with $200-\mu \mathrm{L}$ glass inserts using glass Pasteur pipettes; a new pipette is used for each sample. The sample label is transferred from the sample test tube to the autosampler vial immediately before each sample is pipetted. The sample eluates then are stored in a freezer at $-10{ }^{\circ} \mathrm{C}$ until analysis.

\section{Instrument Analysis Procedure}

Aliquots of the sample eluates are injected and the compounds separated on an Agilent 1100 model D series LC system with a Keystone 250- x 4.6-mm C-18 analytical column. The LC column is equilibrated with the mobile phase for 2 hours prior to analysis by running the LC method three times without an injection and then running the LC method at initial conditions for the remainder of the 2 hours. Mass spectral analysis was conducted using a Waters Quattro Micro API benchtop, triple quadrupole MS system with ESI in negativeion mode using MRM.

8.1 Sample analysis - The LC/MS/MS conditions for the analysis of isoxaflutole and its sequential degradation products are listed below.

\subsubsection{LC conditions:}

Injection volume-20 $\mu \mathrm{L}$;

LC column oven conditions $-50^{\circ} \mathrm{C}$.

8.1.2 LC mobile-phase:
A, 1.5-percent v/v glacial acetic acid in reagent water;
B, methanol. 
Table 2. Liquid chromatography/tandem mass spectrometry analytical sequence for use in determining isoxaflutole and its sequential degradation products, diketonitrile and benzoic acid, in water.

\begin{tabular}{|c|c|c|c|c|c|c|c|c|c|}
\hline \multicolumn{2}{|c|}{$\begin{array}{l}\text { Analytical } \\
\text { sequence }\end{array}$} & \multirow{2}{*}{$\begin{array}{c}\text { Date } \\
\text { received }\end{array}$} & \multirow{2}{*}{ Sample type } & \multirow{2}{*}{$\begin{array}{l}\text { Project } \\
\text { code }\end{array}$} & \multicolumn{2}{|c|}{$\begin{array}{l}\text { Analytical } \\
\text { sequence }\end{array}$} & \multirow{2}{*}{$\begin{array}{c}\text { Date } \\
\text { received }\end{array}$} & \multirow{2}{*}{ Sample type } & \multirow{2}{*}{$\begin{array}{c}\text { Project } \\
\text { code }\end{array}$} \\
\hline $\begin{array}{l}\text { Vial } \\
\text { no. }\end{array}$ & $\begin{array}{c}\text { Triathlon } \\
\text { no. }\end{array}$ & & & & $\begin{array}{c}\text { Vial } \\
\text { no. }\end{array}$ & $\begin{array}{c}\text { Triathlon } \\
\text { no. }\end{array}$ & & & \\
\hline 1 & 1 & & 5 ppt Standard & & 32 & 1 & & $\mathrm{CCV} 1 \mathrm{ppt}$ & \\
\hline 2 & 2 & & $10 \mathrm{ppt}$ Standard & & 33 & 2 & & COB C & \\
\hline 3 & 3 & & 50 ppt Standard & & 34 & 3 & & Sample 1 Set C & \\
\hline 4 & 4 & & 100 ppt Standard & & 35 & 4 & & Sample 2 Set C & \\
\hline 5 & 5 & & 200 ppt Standard & & 36 & 5 & & Sample 3 Set C & \\
\hline 6 & 6 & & COB A & & 37 & 6 & & Sample 4 Set C & \\
\hline 7 & 7 & & Sample 1 Set A & & 38 & 7 & & Sample 5 Set C & \\
\hline 8 & 8 & & Sample 2 Set A & & 39 & 8 & & Sample 6 Set C & \\
\hline 9 & 9 & & Sample 3 Set A & & 40 & 9 & & Sample 7 Set C & \\
\hline 10 & 10 & & Sample 4 Set A & & 41 & 10 & & Sample 8 Set C & \\
\hline 11 & 11 & & Sample 5 Set A & & 42 & 11 & & Sample 9 Set C & \\
\hline 12 & 12 & & Sample 6 Set A & & 43 & 12 & & Sample 10 Set C & \\
\hline 13 & 13 & & Sample 7 Set A & & 44 & 13 & & Sample 1 Set C LD & \\
\hline 14 & 14 & & Sample 8 Set A & & 45 & 14 & & Sample 10 Set C Spike & \\
\hline 15 & 15 & & Sample 9 Set A & & 46 & 15 & & COB D & \\
\hline 16 & 16 & & Sample 10 Set A & & 47 & 16 & & Sample 1 Set D & \\
\hline 17 & 17 & & Sample 1 Set A LD & & 48 & 17 & & Sample 2 Set D & \\
\hline 18 & 18 & & Sample 10 Set A Spike & & 49 & 18 & & Sample 3 Set D & \\
\hline 19 & 19 & & COB B & & 50 & 19 & & Sample 4 Set D & \\
\hline 20 & 20 & & Sample 1 Set B & & 51 & 20 & & Sample 5 Set D & \\
\hline 21 & 21 & & Sample 2 Set B & & 52 & 21 & & Sample 6 Set D & \\
\hline 22 & 22 & & Sample 3 Set B & & 53 & 22 & & Sample 7 Set D & \\
\hline 23 & 23 & & Sample 4 Set B & & 54 & 23 & & Sample 8 Set D & \\
\hline 24 & 24 & & Sample 5 Set B & & 55 & 24 & & Sample 9 Set D & \\
\hline 25 & 25 & & Sample 6 Set B & & 56 & 25 & & Sample 10 Set D & \\
\hline 26 & 26 & & Sample 7 Set B & & 57 & 26 & & Sample 1 Set D LD & \\
\hline 27 & 27 & & Sample 8 Set B & & 58 & 27 & & Sample 10 Set D Spike & \\
\hline 28 & 28 & & Sample 9 Set B & & 59 & 28 & & $\mathrm{CCV} 1 \mathrm{ppt}$ & \\
\hline 29 & 29 & & Sample 10 Set A & & 60 & 29 & & COB E & \\
\hline 30 & 30 & & Sample 1 Set B LD & & 61 & 30 & & & \\
\hline \multirow[t]{2}{*}{31} & 31 & & Sample 10 Set B Spike & & 62 & 31 & & & \\
\hline & 32 & & & & & 32 & & & \\
\hline
\end{tabular}


8.1.3 Gradient-

\begin{tabular}{ccc}
\hline Time (min) & $\begin{array}{c}\text { Mobile-phase } \\
\text { A (percent) }\end{array}$ & $\begin{array}{c}\text { Mobile- } \\
\text { phase B } \\
\text { (percent) }\end{array}$ \\
\hline 0.00 & 90 & 10 \\
1.00 & 90 & 10 \\
1.01 & 60 & 40 \\
10.00 & 20 & 80 \\
16.00 & 20 & 80 \\
\hline
\end{tabular}

8.1.4 Flow rate $-0.40 \mathrm{~mL} / \mathrm{min}$.

8.1.5 MS/MS source parameters:

MS ionization mode-ESI in negative-ion mode;

Capillary voltage $-2,000 \mathrm{~V}$;

Extractor voltage - 1 V;

Radio frequency $(\mathrm{RF})$ lens voltage $-0.1 \mathrm{~V}$;

Source temperature- $100^{\circ} \mathrm{C}$;

Desolvation temperature- $350^{\circ} \mathrm{C}$;

Cone gas flow-40 L/hr; and

Desolvation gas flow-540 L/hr.

8.1.6 Quadrupole 1 parameters:

Low mass (LM 1) resolution-13;

High mass (HM 1) resolution-13; and

Ion energy-1.0.

8.1.7 Collision cell parameters:

Entrance -3 and Exit-3.

8.1.8 Quadrupole 2 parameters:

Low mass (LM 2) resolution-15;

High mass (HM 2) resolution-15;

Ion energy-2.0; and

Photo multiplier-650 V.

8.1.9 Data acquisition and processing - The data are acquired using Waters MassLynx and quantified using the Waters QuanLynx data analysis program.

8.2 Liquid chromatograph (LC) performance evaluationBackground absorbance readings, peak shape, and system pressure are used to evaluate LC performance. Background absorbance readings should remain stable and low and indicate that the LC column is equilibrated with the mobile-phase flow. If peak shape deteriorates, the columns may need to be cleaned or replaced. If the pressure reading is high, there may be a clog in the mobile-phase flow path or the column compartment thermostat may not have reached the required temperature.

8.3 Mass spectrometer (MS) performance evaluation-For the MS, a static, scanning, and scan-speed compensation mass calibration of the quadrupoles is performed every
6 months unless mass "drift" is identified as a problem. The MRM transition parameters (cone voltage and collision energy) needed to maximize the response of the molecular-hydrogen (M-H, precursor)- and product-ion transitions for each compound are listed in table 3 . The tune and MRM parameters are optimized by infusing $50-\mathrm{mg} / \mathrm{mL}$ solutions of each individual compound into the mobile phase with a " $\mathrm{T}$ " fitting at $10 \mu \mathrm{L} / \mathrm{min}$ using a syringe pump. The MS tune parameters for the source and quadrupole 1 are adjusted to optimize the response of the $\mathrm{M}-\mathrm{H}$ ion for isoxaflutole, DKN, BA, and the internal standard and surrogate standard and the collision cell, and quadrupole 2 parameters are adjusted to identify and optimize response of the daughter ions.

The MS performance is evaluated prior to each sample run by injecting $20 \mu \mathrm{L}$ of the $0.123-\mathrm{ng} / \mu \mathrm{L}$ working standard mix and assessing product-ion abundances and ratios. If the abundances are low, the general tune parameters and compound specific tune parameters are reoptimized.

\section{Quality Assurance and Quality Control (OA/OC)}

The quality-control program consists of primarily internal checks on precision and accuracy of analytical results. Laboratory quality-control data from continuous calibration verification (CCV), laboratory blank and spike samples, and internal and surrogate standards are used by the analyst to determine if corrective actions are needed. Field sampling errors also are determined by the analyst.

9.1 Field sampling-Accuracy of the handling of samples in the field is monitored when field blanks and field replicates are included for analysis by the laboratory. Each sample is handled separately for proper data determination by the analyst.

\subsection{Continuous calibration verification (CCV)-The CCV} solutions, which are reagent-water spike samples, are used to monitor the method stability in comparison to the initial calibration curve. The CCV control limits are established at \pm 25 percent of the expected concentration for each compound. If a CCV fails the QC criteria, the affected samples are reanalyzed. The CCV results are compiled for long-term method recovery performance used for creating control limits and charts. If the recovery of a compound is not within control limits, the source of the problem must be identified and corrected before continuing the procedure.

9.3 Internal standards - Internal standards are added to correct quantitative results for slight differences in extract volume as well as compensate for differences in the injected sample volume. They also are used to monitor instrument conditions, such as extract injection errors, retention time shifts, or instrument abnormalities or malfunctions. 
Table 3. Retention times and multiple-reaction monitoring molecular (precursor)-ion and product-ion transitions for isoxaflutole, its two sequential degradation products, and the internal and surrogate standards.

[ISTD, internal standard; M-H, molecular-hydrogen; m/z, mass-to-charge ratio; V, volts; --, no data]

\begin{tabular}{|c|c|c|c|c|c|c|c|}
\hline Compound & $\begin{array}{l}\text { Retention } \\
\text { time } \\
\text { (minutes) }\end{array}$ & $\begin{array}{c}\text { Molecular } \\
\text { (precursor) ion } \\
\text { M-H } \\
(\mathrm{m} / \mathrm{z})\end{array}$ & $\begin{array}{c}\text { Cone } \\
\text { (V) }\end{array}$ & $\begin{array}{l}\text { Quantitation } \\
\text { product } \\
\text { ion } \\
(\mathrm{m} / \mathrm{z})\end{array}$ & $\begin{array}{l}\text { Col- } \\
\text { lision } \\
\text { energy } \\
\text { (V) }\end{array}$ & $\begin{array}{l}\text { Confirming } \\
\text { product } \\
\text { ion } \\
(\mathrm{m} / \mathrm{z}) \\
\end{array}$ & $\begin{array}{c}\text { Col- } \\
\text { lision } \\
\text { energy } \\
\text { (V) }\end{array}$ \\
\hline \multicolumn{8}{|c|}{ Herbicide and degradation products } \\
\hline Isoxaflutole & 12.84 & 357.9 & 25 & 78.9 & 13 & 277.6 & 13 \\
\hline Diketonitrile & 9.92 & 357.9 & 25 & 78.9 & 13 & 277.6 & 13 \\
\hline Benzoic acid & 9.44 & 267.0 & 19 & 159.0 & 15 & 223.1 & 15 \\
\hline \multicolumn{8}{|c|}{ Internal standard } \\
\hline ISTD, 2,4-dichlorophenoxyacetic acid-d ${ }_{3}$ & 13.36 & 222.0 & 20 & 164.0 & 12 & -- & -- \\
\hline \multicolumn{8}{|c|}{ Surrogate standard } \\
\hline Alachlor ethanesulfonic acid (ESA)- $\mathrm{d}_{5}$, & 11.28 & 319.0 & 40 & 121.0 & 26 & -- & -- \\
\hline
\end{tabular}

9.4 Laboratory blank-The laboratory blank (carryover blank, $\mathrm{COB})$ is reagent water prepared to monitor the entire sample preparation and analytical procedure for possible laboratory contamination. The blank is acceptable when a compound is undetected or detected at five times less than the method reporting limit (MRL). On the basis of data from this method, there are no interferences in the laboratory blanks.

9.5 Laboratory matrix spike-The laboratory matrix spike is an aliquot of an environmental sample to which known quantities of the method analytes are added in the laboratory. The laboratory matrix spike is analyzed exactly like a sample, and its purpose is to measure recovery by determining whether the sample matrix contributes bias to the analytical results and, therefore, determines to what degree the method is successful in analyzing the target analytes. The background concentrations of the analytes in the sample matrix must be determined in a separate aliquot, and the measured values in the laboratory matrix spike corrected for background concentrations.

9.6 Surrogate standards-Surrogate standards are compounds similar in physical and chemical properties to the method compounds but are not expected to be present in the environment. They are added to each environmental and QA/QC sample and used to monitor matrix effects and overall method performance. Their recoveries are not used to correct compound concentrations in environmental samples.

9.7 Instrumental analysis quality control-A sample analytical sequence used for this method is listed in table 2. Sample extracts are analyzed in an instrument sequence to provide additional information to facilitate corrective actions that might be required if performance criteria are not met.

\section{Calculation of Results}

Before quantitative results are reported, each compound first needs to meet qualitative criteria.

10.1 Qualitative Identification-Identification and quantitation of compounds are performed on the raw data files using MassLynx with the Quan-Lynx data analysis package. A compound is not identified correctly unless the correct molecular (precursor)- to product-ion transitions are detected, the relative ratio of the confirming to quantitation daughter ion is within \pm 25 percent of the average ratio obtained from the calibration samples, and the relative retention time is within 5 percent of the expected retention time.

10.2 Quantitation - The concentration of a compound is calculated according to the calibration curve used to establish the best fit between the calibration points after the compound has passed qualitative criteria. Linearregressed five-point standard curves are constructed from the calibration standards. The correlation coefficient for each standard curve has to be greater than or equal to 0.99 to be accepted.

10.3 Calculations - If a selected compound has passed the qualitative identification criteria, the concentration in the sample is calculated as follows:

$$
C=((A c / A i)(m)+y)(D F), \text { in micrograms per liter, }
$$

where

$$
\begin{aligned}
C= & \text { concentration of the selected compound in } \\
& \text { the sample, in micrograms per liter; } \\
A c= & \text { area of peak of the quantitation ion for the } \\
& \text { selected compound; } \\
A i= & \text { area of peak of the quantitation ion for the }
\end{aligned}
$$


internal standard;

$m \quad$ = slope of calibration curve using extracted standards between the selected compound and the internal standard from the original calibration data;

$y$

$=$ intercept of calibration curve between the selected compound and the internal standard from the original calibration data; and

$D F \quad=$ dilution factor calculated using equation 4 .

The internal standard is used as a retention-time reference and for quantitation. The relative retention time $\left(R R T_{\mathrm{c}}\right)$ is calculated for each selected compound in the calibration samples or in a sample as follows:

$$
R R T_{\mathrm{c}}=R T_{\mathrm{c}} / R T_{\mathrm{i}},
$$

where

$$
\begin{aligned}
R T_{\mathrm{c}}= & \text { uncorrected retention time of the selected } \\
& \text { compound, and } \\
R T_{\mathrm{i}}= & \text { uncorrected retention time of the internal } \\
& \text { standard. }
\end{aligned}
$$

See table 2 for retention times, molecular (precursor)and quantitation- and confirming product-ion transition pairs. The expected retention time $(R T)$ of the peak of the selected compound needs to be within \pm 5 percent of the expected retention time on the basis of the $R R T_{\mathrm{c}}$. The expected retention time is calculated as follows:

$$
R T=\left(R R T_{\mathrm{c}}\right)\left(R T_{\mathrm{i}}\right)
$$

where

$$
\begin{aligned}
R T= & \text { expected retention time of the selected } \\
& \text { compound, } \\
R R T_{\mathrm{c}}= & \text { relative retention time of the selected } \\
& \text { compound, and } \\
R T_{\mathrm{i}}= & \begin{array}{l}
\text { uncorrected retention time of the internal } \\
\text { standard. }
\end{array}
\end{aligned}
$$

The dilution factor $(D F)$ of the processed sample is calculated using equation 4 :

$$
D F=\left(123 / 123-V_{\mathrm{np}}\right)\left(123 / 123-V_{\mathrm{a}}\right),
$$

where

$$
\begin{aligned}
D F= & \text { dilution factor, } \\
V_{\mathrm{np}}= & \text { volume not pumped = milliliters not } \\
& \text { pumped through the SPE column, and } \\
V_{\mathrm{a}}= & \text { volume added = millilliters of distilled } \\
& \text { water added to a sample that contained less } \\
& \text { than } 123 \mathrm{~mL} .
\end{aligned}
$$

The $D F$ is incorporated into the calculation for determining final concentrations of samples. Initial calibration data are acceptable if the correlation coefficient $\left(\mathrm{r}^{2}\right)$ value for all curves is greater than or equal to 0.990 for all compounds. A quadratic formula is used for curve fitting. A complete extracted calibration curve is included within each instrument sequence.

\section{Reporting of Data Results}

Isoxaflutole, DKN, and BA are reported in concentrations ranging from 0.003 to $0.20 \mu \mathrm{g} / \mathrm{L}$. If the concentration is greater than $0.250 \mu \mathrm{g} / \mathrm{L}$, a portion of the original sample is diluted appropriately with reagent water and reanalyzed.

\section{Method Performance}

Method performance was evaluated for SPE recovery using 0.10 - and $0.20-\mu \mathrm{g} / \mathrm{L}$ reagent-water spikes. Method performance also was evaluated at two different spiked levels $(0.02$ and $0.10 \mu \mathrm{g} / \mathrm{L})$ for four sample matrices analyzed over different days. The four sample matrices consisted of reagent water; a ground-water sample collected from a well in Sedgwick County, Kansas; a surface-water sample from Poison Creek near Grandview, Idaho; and a surface-water sample from the spillway below Clinton Lake in Kansas. All samples were filtered through a nominal $0.7-\mu \mathrm{m}$ glass fiber filter and stored at $4{ }^{\circ} \mathrm{C}$. Method detection limit (MDL) and method reporting level (MRL) were determined using multiple $0.010-\mu \mathrm{g} / \mathrm{L}$ reagent-water spikes.

12.1 Method recovery-The recovery of isoxaflutole, DKN, and BA from the SPE cartridges was determined by comparing eight spiked reagent-water samples (two at $0.02 \mu \mathrm{g} / \mathrm{L}$ and six at $0.10 \mu \mathrm{g} / \mathrm{L}$ ) to theoretical 100 -percent recovery solutions (table 4 ). The theoretical 100-percent recovery solutions were prepared by adding the same volumes of working standard, surrogate standard, and internal standard mixes to test tubes with the SPE eluting solvent as they were spiked into the 0.10 - and $0.20-\mu \mathrm{g} / \mathrm{L}$ reagent-water samples prepared for SPE. The spiked theoretical 100-percent recovery solutions and the SPEextracted samples eluated then were evaporated to $200 \mu \mathrm{L}$ and stored at $-10{ }^{\circ} \mathrm{C}$ until analysis. Table 4 shows that the mean SPE recoveries varied from 104 to 108 percent for isoxaflutole, DKN, and BA with relative standard deviation percentages of 4.0 to 10.6 percent.

12.2 Matrix performance-To evaluate general method performance, 123-mL sample aliquots of each of the four samples matrices were spiked with isoxaflutole, DKN, and BA at concentrations of 0.02 and $0.10 \mu \mathrm{g} / \mathrm{L}$ and analyzed on eight different days so that comparison of different matrices and concentrations included bias from day-to-day variation. In addition, unspiked samples of each matrix were extracted and analyzed to determine background concentrations of isoxaflutole, DKN, and BA. All subsamples were analyzed at the USGS OGRL using one LC/MS/MS system. Eight subset sample sets were spiked during February 23 through March 5, 2004. However, one subset of the reagent water was lost during analysis leaving only seven subsets of the $0.02-\mu \mathrm{g} / \mathrm{L}$ spiked reagent water. 
Table 4. Summary of mean solid-phase extraction recovery and relative standard deviation percentages in buffered reagent water for isoxaflutole, diketonitrile, benzoic acid, and the surrogate standard.

\begin{tabular}{lcc}
\hline Compound & $\begin{array}{c}\text { Mean } \\
\text { solid-phase } \\
\text { extraction } \\
\text { recovery } \\
\text { (percent) }\end{array}$ & $\begin{array}{c}\text { Relative } \\
\text { standard } \\
\text { deviation } \\
\text { (percent) }\end{array}$ \\
\hline Isoxaflutole & 104 & 10.6 \\
Diketonitrile & 108 & 7.0 \\
Benzoic acid & 105 & 4.0 \\
\hline \multicolumn{3}{c}{ Surrogate standard } \\
\hline Alachlor ethanesulfonic acid (ESA)- $\mathrm{d}_{3}$, & 101 & 9.0 \\
\hline
\end{tabular}

Table 5 shows the mean concentration and standard deviation for isoxaflutole, DKN, BA, and the surrogate standard for each of the four sample matrices, and table 6 shows the combined mean and standard deviation of these compounds for the four matrices. These data show that the mean concentration among the sample matrices for isoxalfutole, DKN, and BA varied from 0.011 to $0.021 \mu \mathrm{g} / \mathrm{L}$ and 0.051 to $0.10 \mu \mathrm{g} / \mathrm{L}$ for the 0.02 - and $0.10-\mu \mathrm{g} / \mathrm{L}$ spiked samples, respectively (table 5). The combined mean of concentrations of isoxalfutole, DKN, and BA for all four matrices varied from 0.016 to $0.021 \mu \mathrm{g} / \mathrm{L}$ and 0.075 to $0.10 \mu \mathrm{g} / \mathrm{L}$ for the $0.02-$ and $0.10-\mu \mathrm{g} / \mathrm{L}$ spiked samples, respectively (table 6). The calculated mean and combined mean concentrations of the surrogate standards are close to $0.50 \mu \mathrm{g} / \mathrm{L}$ across all matrices.

Tables 5 and 6 also show the mean and combined mean concentrations, respectively, normalized as a percentage of the theoretical spiked concentrations. The data in table 5 show that the mean concentrations for isoxaflutole and DKN were 80 to 102 percent of the theoretical spiked concentrations in the ground- and reagent-water samples and were 70 to 76 percent of the theoretical spiked concentrations in the Poison Creek surface-water sample and 51 to 59 percent of the theoretical spiked concentrations for the Clinton Lake samples. Benzoic acid calculated concentrations are 94 to 106 percent of the theoretical spiked concentrations for all four water matrices. Table 6 shows that the combined mean for isoxaflutole and DKN was 75 to 81 percent of the theoretical spiked concentration with relative standard deviations ranging from 3 to 26 percent, whereas the combined mean for BA ranged from 100 to 101 percent of the theoretical spiked concentation with a relative standard deviation ranging from 3 to 5 percent. The combined mean concentration of the surrogate standard ranged from 99 to 101 percent with relative standard deviations less than 2 percent.

The data in table 5 show that within sample sets that the precision was good for isoxaflutole, DKN, and BA with relative standard deviations generally less than 10 percent at both the 0.02 - and $0.10-\mu \mathrm{g} / \mathrm{L}$ spike levels. The data in table 6 show that isoxaflutole and DKN exhibited more variation in concentration among matrices than BA or the surrogate standard.

\subsection{Method detection limit (MDL) and reporting level} $(M R L)$ - A laboratory standard normally contains only the compounds of interest that do not interfere with and even might enhance the performance of the analytical instrument. Under these circumstances, the analytical system provides the minimum concentration that can be identified, measured, and reported with a 99-percent confidence that the compound concentration is greater than zero, while minimizing uncertainty due to matrix effects, which is referred to as the method detection limit (MDL). On the other hand, an environmental sample may not only contain the compounds of interest in relatively smaller concentrations but also many nontargeted compounds that can interfere with the sample analysis. Any deviation from the ideal laboratory sample results are accounted for in the method reporting level (MRL), which is the corrected concentration reportable for that sample under these conditions. The MRL is always equal to or greater than the MDL.

MDLs are determined according to procedures outlined by the U.S. Environmental Protection Agency (1992). Eight replicate samples of buffered reagent water are spiked at $0.010 \mu \mathrm{g} / \mathrm{L}$ with the working standard mix. Each set of duplicate samples was analyzed on different days during February 2004 so that day-to-day variation is included in the results.

The MDL was calculated using the following equation:

$$
\mathrm{MDL}=(\mathrm{SD})\left[{ }^{\mathrm{t}}(\mathrm{n}-1,1-\partial=0.99)\right]
$$

where

$$
\begin{aligned}
\mathrm{SD}= & \text { standard deviation of replicate } \\
& \text { analysis, in micrograms } \\
& \text { per liter, at the spiked } \\
& \text { concentration; } \\
\left.\mathrm{C}^{\mathrm{t}}(\mathrm{n}-1,1-\partial=0.99)\right]= & \text { Student's t-value for the 99- } \\
& \text { percent confidence level with } \\
& \mathrm{n}-1 \text { degrees of freedom (U.S. } \\
& \text { Environmental Protection } \\
& \text { Agency, 1992); and } \\
= & \text { number of replicate analyses. }
\end{aligned}
$$

The calculated MDL is $0.003 \mu \mathrm{g} / \mathrm{L}$ for isoxaflutole and diketonitrile and $0.004 \mu \mathrm{g} / \mathrm{L}$ for benzoic acid. According to the U.S. Environmental Protection Agency procedure, the spiked concentrations should be no more than five times the estimated MDL. The spiked concentrations are within five times of the MDL. The MRL is calculated by multiplying the SD of the $0.010-\mu \mathrm{g} / \mathrm{L}$ reagent-water spikes by 10 (U.S. Environmental Protection Agency, 1992). The calculated MRL is 0.011 for isoxaflutole, 0.010 for diketonitrile, and $0.012 \mu \mathrm{g} / \mathrm{L}$ for benzoic acid. On the basis of calculated MDLs and MRLs and evaluation of the signal-to-noise ratios for each compound, the MRLs and MDLs are set at 0.010 and $0.003 \mu \mathrm{g} / \mathrm{L}$, respectively, for all three compounds. 
Table 5. Summary of mean concentrations, standard deviations, and mean normalized percentage of theoretical spiked concentrations and relative percentage standard deviations for isoxaflutole, diketonitrile, benzoic acid, and the surrogate standard in four water matrices.

[ $\mu \mathrm{g} / \mathrm{L}$, microgram per liter; $\mathrm{n}$, number of samples]

\begin{tabular}{|c|c|c|c|c|c|c|c|c|}
\hline \multicolumn{9}{|c|}{ Reagent water } \\
\hline \multirow[b]{2}{*}{ Compound } & \multicolumn{4}{|c|}{ Spiked at $0.02 \mu \mathrm{g} / \mathrm{L}(\mathrm{n}=7)$} & \multicolumn{4}{|c|}{ Spiked at $0.10 \mu \mathrm{g} / \mathrm{L}(\mathrm{n}=8)$} \\
\hline & $\begin{array}{c}\text { Mean } \\
\text { concentration } \\
(\mu \mathrm{g} / \mathrm{L})\end{array}$ & $\begin{array}{c}\text { Standard } \\
\text { deviation } \\
(\mu \mathrm{g} / \mathrm{L})\end{array}$ & $\begin{array}{c}\text { Mean } \\
\text { normalized } \\
\text { concentration } \\
\text { (percent) }\end{array}$ & $\begin{array}{l}\text { Relative } \\
\text { standard } \\
\text { deviation } \\
\text { (percent) }\end{array}$ & $\begin{array}{c}\text { Mean } \\
\text { concentration } \\
(\mu \mathrm{g} / \mathrm{L})\end{array}$ & $\begin{array}{c}\text { Standard } \\
\text { deviation } \\
(\mu \mathrm{g} / \mathrm{L})\end{array}$ & $\begin{array}{c}\text { Mean } \\
\text { normalized } \\
\text { concentration } \\
\text { (percent) }\end{array}$ & $\begin{array}{l}\text { Relative } \\
\text { standard } \\
\text { deviation } \\
\text { (percent) }\end{array}$ \\
\hline Isoxaflutole & 0.020 & 0.0008 & 101.3 & 4.10 & 0.097 & 0.0038 & 97.2 & 3.88 \\
\hline Benzoic acid & .020 & .0015 & 102.0 & 7.42 & .099 & .0035 & 99.8 & 3.49 \\
\hline Surrogate standard & .490 & .0290 & 98.6 & 5.81 & .500 & .0244 & 99.4 & 4.91 \\
\hline \multicolumn{9}{|c|}{ Ground water, Sedgwick County, Kansas } \\
\hline & \multicolumn{4}{|c|}{ Spiked at $0.02 \mu \mathrm{g} / \mathrm{L}(\mathrm{n}=8)$} & \multicolumn{4}{|c|}{ Spiked at $0.10 \mu \mathrm{g} / \mathrm{L}(\mathrm{n}=8)$} \\
\hline Isoxaflutole & 0.017 & 0.0015 & 80.5 & 8.88 & 0.081 & 0.0071 & 81.6 & 8.71 \\
\hline Diketonitrile & .018 & .0011 & 90.2 & 6.31 & .090 & .0030 & 89.7 & 3.37 \\
\hline Benzoic acid & .021 & .0014 & 101.2 & 6.94 & .104 & .0024 & 104.4 & 2.28 \\
\hline Surrogate standard & .500 & .0240 & 99.7 & 4.87 & .500 & .0350 & 100.6 & 6.94 \\
\hline \multicolumn{9}{|c|}{ Surface water, Poison Creek near Grandview, Idaho } \\
\hline & \multicolumn{4}{|c|}{ Spiked at $0.02 \mu \mathrm{g} / \mathrm{L}(\mathrm{n}=8)$} & \multicolumn{4}{|c|}{ Spiked at $0.10 \mu \mathrm{g} / \mathrm{L}(\mathrm{n}=8)$} \\
\hline Compound & $\begin{array}{c}\text { Mean } \\
\text { concentration } \\
(\mu \mathrm{g} / \mathrm{L})\end{array}$ & $\begin{array}{c}\text { Standard } \\
\text { deviation } \\
(\mu \mathrm{g} / \mathrm{L})\end{array}$ & $\begin{array}{c}\text { Mean } \\
\text { normalized } \\
\text { concentration } \\
\text { (percent) }\end{array}$ & $\begin{array}{l}\text { Relative } \\
\text { standard } \\
\text { deviation } \\
\text { (percent) }\end{array}$ & $\begin{array}{c}\text { Mean } \\
\text { concentration } \\
(\mu \mathrm{g} / \mathrm{L})\end{array}$ & $\begin{array}{c}\text { Standard } \\
\text { deviation } \\
(\mu \mathrm{g} / \mathrm{L})\end{array}$ & $\begin{array}{c}\text { Mean } \\
\text { normalized } \\
\text { concentration } \\
\text { (percent) }\end{array}$ & $\begin{array}{l}\text { Relative } \\
\text { standard } \\
\text { deviation } \\
\text { (percent) }\end{array}$ \\
\hline \multicolumn{9}{|c|}{ Surface water, Clinton Lake, Lawrence, Kansas } \\
\hline & \multicolumn{4}{|c|}{ Spiked at $0.02 \mu \mathrm{g} / \mathrm{L}(\mathrm{n}=8)$} & \multicolumn{4}{|c|}{ Spiked at $0.10 \mu \mathrm{g} / \mathrm{L}(\mathrm{n}=8)$} \\
\hline Compound & $\begin{array}{c}\text { Mean } \\
\text { concentration } \\
(\mu \mathrm{g} / \mathrm{L})\end{array}$ & $\begin{array}{c}\text { Standard } \\
\text { deviation } \\
(\mu \mathrm{g} / \mathrm{L})\end{array}$ & $\begin{array}{c}\text { Mean } \\
\text { normalized } \\
\text { concentration } \\
\text { (percent) }\end{array}$ & $\begin{array}{l}\text { Relative } \\
\text { standard } \\
\text { deviation } \\
\text { (percent) }\end{array}$ & $\begin{array}{c}\text { Mean } \\
\text { concentration } \\
(\mu \mathrm{g} / \mathrm{L})\end{array}$ & $\begin{array}{c}\text { Standard } \\
\text { deviation } \\
(\mu \mathrm{g} / \mathrm{L})\end{array}$ & $\begin{array}{c}\text { Mean } \\
\text { normalized } \\
\text { concentration } \\
\text { (percent) }\end{array}$ & $\begin{array}{l}\text { Relative } \\
\text { standard } \\
\text { deviation } \\
\text { (percent) }\end{array}$ \\
\hline Isoxaflutole & 0.012 & 0.0015 & 59.3 & 12.70 & 0.051 & 0.0049 & 50.6 & 9.64 \\
\hline Diketonitrile & .011 & .0011 & 55.3 & 9.70 & .052 & .0042 & 52.4 & 8.00 \\
\hline Benzoic acid & .019 & .0015 & 95 & 7.64 & .094 & .0068 & 94.1 & 7.19 \\
\hline Surrogate standard & .50 & .0330 & 99 & 6.55 & .510 & .0360 & 102.7 & 6.91 \\
\hline
\end{tabular}


Table 6. Combined mean concentrations, standard deviations, and combined mean normalized percentage of theoretical spiked concentrations and relative percentage standard deviations for isoxaflutole, diketonitrile, benzoic acid, and the surrogate standard in four water matrices.

[ $\mu \mathrm{g} / \mathrm{L}$, microgram per liter; $\mathrm{n}$, number of matrices]

\begin{tabular}{|c|c|c|c|c|c|c|c|c|}
\hline \multirow[b]{2}{*}{ Compound } & \multicolumn{4}{|c|}{ Spiked at $0.02 \mu \mathrm{g} / \mathrm{L}(\mathrm{n}=4)$} & \multicolumn{4}{|c|}{ Spiked at $0.10 \mu \mathrm{g} / \mathrm{L}(\mathrm{n}=4)$} \\
\hline & $\begin{array}{c}\text { Mean } \\
\text { concentra- } \\
\text { tion } \\
(\mu \mathrm{g} / \mathrm{L})\end{array}$ & $\begin{array}{c}\text { Standard } \\
\text { deviation } \\
(\mu \mathrm{g} / \mathrm{L})\end{array}$ & $\begin{array}{c}\text { Mean } \\
\text { normalized } \\
\text { concentra- } \\
\text { tion } \\
\text { (percent) }\end{array}$ & $\begin{array}{l}\text { Relative } \\
\text { standard } \\
\text { deviation } \\
\text { (percent) }\end{array}$ & $\begin{array}{c}\text { Mean } \\
\text { concentra- } \\
\text { tion } \\
(\mu \mathrm{g} / \mathrm{L})\end{array}$ & $\begin{array}{l}\text { Standard } \\
\text { deviation } \\
(\mu \mathrm{g} / \mathrm{L})\end{array}$ & $\begin{array}{c}\text { Mean } \\
\text { normalized } \\
\text { concentra- } \\
\text { tion } \\
\text { (percent) }\end{array}$ & $\begin{array}{l}\text { Relative } \\
\text { standard } \\
\text { deviation } \\
\text { (percent) }\end{array}$ \\
\hline Isoxaflutole & 0.016 & 0.0037 & 78 & 23 & 0.075 & 0.0196 & 75 & 26 \\
\hline Diketonitrile & .016 & .0040 & 81 & 25 & .080 & .0204 & 80 & 26 \\
\hline Benzoic acid & .021 & .0007 & 100 & 3.3 & .101 & .0054 & 101 & 5.4 \\
\hline Surrogate standard & .500 & .0037 & 99 & .74 & .500 & .0080 & 101 & 1.5 \\
\hline
\end{tabular}

\section{Conclusions}

This method provides for routine analysis of isoxaflutole and its sequential degradation products, diketonitrile (DKN) and benzoic acid analogue (BA), in filtered ground- and surface-water samples. The method demonstrates that solid-phase extraction (SPE) coupled with liquid chromatography/tandem mass spectrometry (LC/MS/MS) can be used to analyze water for these compounds.

The analytical method showed good precision, with generally less than 10 percent relative standard deviation within a water matrix. Analysis of BA and the surrogate standard showed good accuracy and precision within and among matrices. For isoxaflutole and DKN, the mean calculated concentrations were within 30 percent of the theoretical spiked concentrations for three of the sample matrices and were within 50 percent of the theoretical spiked concentration for the surface-water sample from Clinton Lake, Kansas.

Compound detection limits (MDLs) and reporting levels (MRLs) were calculated using U.S. Environmental Protection Agency procedures. The MDL for isoxaflutole and diketonitrile is $0.003 \mu \mathrm{g} / \mathrm{L}$ and $0.004 \mu \mathrm{g} / \mathrm{L}$ for benzoic acid. MRLs are $0.011,0.010$, and $0.012 \mu \mathrm{g} / \mathrm{L}$ for isoxaflutole, diketonitrile, and benzoic acid, respectively. On the basis of calculated MDLs and MRLs and evaluation of the signal-to-noise ratios for each compound, the MRLs and MDLs are set at 0.010 and $0.003 \mu \mathrm{g} / \mathrm{L}$, respectively, for all three compounds.

Information about the fate and transport of isoxaflutole and its two sequential degradation products, DKN and BA, in water can be acquired from the analysis of ground water and surface water. The method was tested and successfully used to analyze 75 samples from 10 Iowa streams between March and September 2004. This method will contribute to an improved understanding of the occurrence, persistence, and transport of isoxaflutole and its sequential degradation products in the environment.

\section{References Cited}

Lin, C.H., Lerch, R.N., Thurman, E.M., Garrett, H.E., and George, M.F., 2002, Determination of isoxaflutole (Balance) and its metabolites in water using solid-phase extraction followed by high-performance liquid chromatography with ultraviolet or mass spectrometry: Journal of Agriculture and Food Chemistry, v. 50, p. 5816-5824.

Pallet, K.E., Cramp, S.M., Little, J.P., Veerasekaran, P., Crudace, A.J., and Slater, A.E., 2001, Isoxaflutole-the background to its discovery and the basis of its herbicidal properties: Pesticide Management Science, v. 57, p. 133.

Shelton, L.R., 1994, Field guide for collection and processing stream-water samples for the National Water-Quality Assessment Program: U.S. Geological Survey Open-File Report 94-455, $42 \mathrm{p}$.

Scribner, E.A., Meyer, M.T., and Kalkhoff, S.J., 2006, Occurrence of isoxaflutole, acetamide, and triazine herbicides and their degradation products in 10 Iowa rivers draining to the Mississippi and Missouri Rivers, 2004: U.S. Geological Survey Scientific Investigations Report 2006-5169, 84 p.

U.S. Department of Agriculture, 2004, National Agricultural Statistics Service (NASS) agriculture chemical use database: Information available on the Web, accessed February 6,2006, at http://www.pestmanagement.info/nass/

U.S. Environmental Protection Agency, 1992, Guidelines establishing test procedures for the analysis of pollutants (appendix B, part 136, Definition and procedures for the determination of the method detection limit): U.S. Code of Federal Regulations, Title 40, revised as of July 1, 1992, p. 565-567. 
Viviani, F., Little, J.P., and Pallett, K.E., 1998, The mode of action of isoxaflutole II-characterization of the inhibition of carrot 4-hydroxyphenylpyruvate dioxygenase by diketonitrile derivative of isoxaflutole: Pesticide Biochemistry and Physiology, v. 62, no. 2, p. 125-134.

Webb, W.E., Radtke, D.B., and Iwatsubo, R.T., 1999, Surface-water sampling collection methods at flowing-water and still-water sites: U.S. Geological Survey Techniques in Water-Resources Investigations, book 9, chap. A4, section 4.1, p. 23-59.
Wilde, F.D., Radtke, D.B., Gibs, Jacob, and Iwatsubo, R.T., 1998, National field manual for the collection of waterquality data - preparations for water sampling: U.S. Geological Survey Techniques of Water-Resources Investigations, book 9, chap. A1-A5 [variously paged]. 
Prepared by Lawrence Publishing Service Center. Edited by Lanna Combs.

Graphics by Jeff Hartley and Mike Kemppainen.

Layout and design by Kristi Hartley.

For more information concerning the research described in this report, contact:

U.S. Geological Survey

4821 Quail Crest Place

Lawrence, KS 66049

(785) 842-9909

http://ks.water.usgs.gov 


\section{宽}

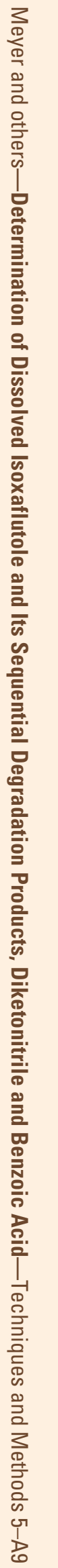

